\title{
The Power of the King of Java in the Indonesian Novel
}

\author{
Gatot Sarmidi*, Suryantoro \\ Universitas PGRI Kanjuruhan Malang \\ Malang, Indonesia \\ *gatotsarmidi@gmail.com, suryantoro.kaka@gmail.com
}

\begin{abstract}
Indonesian literature reflects and represents the power narrated by the figures of the kings of Java. The narrative can be seen in the novels of Airlangga, Arok Dedes, and Minak Jinggo Sekar Kedaton. Research that uses socio-historical approach is analysed based on critical discourse analysis and interpreted using hermeneutics as a qualitative descriptive research method. The result of this study are in the form of descriptive and power conflicts of Javanese kings in the Airlangga, Arok Dedes, and Minak Jinggo Sekar Kedaton novels from the ideological, sociological, and cultural aspects which presented critically according to their review. Ideologically, sociologically and culturally presented in the novel Airlangga, Arok Dedes, and Minak Jinggo Sekar Kedston are nostalgic representations of history and heroism, Javanese human history which is full of intrigue, division, resistance, heroism, and struggle for rights, thrones, property, dignity and self-esteem.
\end{abstract}

Keywords-Javanese kings, Indonesian novels, power, critical discourse analysis, hermeneutical

\section{INTRODUCTION}

Novels are one of the literary genres that are in great demand to read. As literary works, novels represent aesthetic and ethical presentations. Certain novels serve to offer various critical thoughts about morality, ideology, and power. With regard to the aspect of power in novel texts, several Indonesian novels reflect and represent various socio-cultural and historical phenomena. As a basis, literature is a reflection of life that presents an overview of the development of people's thoughts and ideals.

As a mirror of social reality, literature represents ideology and culture. Viewed from the sociology of literature and mimetic views in literature. Reflections and representations of power in the text of the novel provide information that the novel produces thoughts that are not directly conveyed. The description of power in the novel text is presented by the author creatively so that the thoughts in the text of the novel require more adequate interpretations and will make the readers' critical judgments to explore further between historical facts and imagination. As a conflict between historical stories and legend
The subject of power is commonly discussed in critical discourse analysis, namely the discussion of power discourse. In literature, there is a discourse on power in the discussion of hegemony and the representation of power politics in literature. As a discourse, a novel is a form of the author's way of describing, saying and discussing the reality of life events in human life that are represented imaginatively.

Novel as a discourse is a fixation and stabilization of reality, events or experiences into writing. As a discourse, novels are structured, determined and controlled by a particular episteme or represented by appreciation, reflection, reminder, thoughts, ideas and views of reality, events, life experiences and even human life and life itself. In the context of research as a discourse, novel texts have an ideological function and are interpreted based on hermeneutic circles (Review critical discourse analysis [1,2]

In novel works, ideology is seen as creativity that is able to show identity, purpose, status, resources and value systems. As a discourse that represents the authority of the Javanese king ideologically, the study of novels by Indonesian novelists requires a critical attitude. This critical attitude can be observed by looking at the principles and stages of critical discourse analysis. Furthermore, this study focuses on the analysis of the discourse on the power of the Javanese king in Indonesian novels which is limited to the discourse study of power in the novel Airlangga by S.W. Warsito and Harmadi (NA) [3], the novel Arok Dedes by Pramodya Ananta Toer (NAD) [4], and the novel Menak Jinggo Sekar Kedaton by Langit Krisna Hariadi (NMJ) [5].

\section{METHODS}

This critical discourse analysis research [2] on the power of the Javanese king (KRJ) in the Indonesian novel (NI) uses a qualitative approach and uses a descriptive research design with reference to historical information and Nusantara folklore. The data and results obtained in this study are in the form of verbal data or descriptions of reflection and critical representations of the KRJ-NI. As the characteristics of research data, the data source of this research is in the form of novel texts which are determined based on internal sampling or sampling based on criteria or sampling that prioritizes and 
relies on the representation of information that is qualitatively deep, comprehensive, and adequate. As an object of study, the data source validation was selected based on the principles of literary studies, namely based on the features and quality of literary works and excellence, including (1) NA [3], (2) NAD [4], and (3) NMJ [5]. Furthermore, the data collection technique was carried out in accordance with the variables determined using human instruments. The researcher collected data through dialogical interpretation by conducting hermeneutic-structural and historical hermeneutic documentation studies. Interpretive researchers with an understanding and appreciation of data sources, researchers need assistive instruments (secondary in nature). The validity of the data in this study was tested by (1) observation persistence; (2) referral adequacy; (3) ministry discussion and (4) triangulation. Triangulation is carried out both on data, methods, theories and interpretations. Data analysis was carried out using interpretive techniques in order to gain understanding based on the principles of the hermeneutic circle. Data analysis used the interactive-dialectical analysis model and was carried out using the following steps (1) the researcher reads to appreciate and understand hermeneutically all data sources; (2) the researcher identifies and classifies the complete and complete data; (3) the researcher interprets hermeneutically according to the expected goals; and (4) repeat if deemed inadequate and / or discuss with experts and / or colleagues. Data analysis used a flow model, which is carried out simultaneously with data collection, data reduction, data presentation, data interpretation and drawing conclusions. If the results of the conclusions are inadequate, then it is reordered flowing from the beginning accompanied by a process of triangulation and comparison of texts.

\section{RESUlTS AND DISCUSSION}

As a result of research and descriptions of critical reflections and representations of the KRJ-NI on NA, NAD, and NMJ, it shows that the continuity of the kingdoms in Java that are depicted in the novel is undoubtedly coloured with intrigue, conspiracy to seize property, throne, and women. NA, NAD, and NMJ reflect the same thing. Airlangga, the main character of NA, described the royal conflict over the establishment of Kahuripan which later split the kingdom into two, namely Daha and Jenggala. Ken Arok was the main character of NAD over the power struggle of Tunggul Ametung and Ken Dedes over Tumapel which later Ken Arok became king of Singhasari. Likewise, Minak Jinggo, a figure from the Blambangan region in the context of the power struggle over the inner Majapahit king (NMJ).

In Javanese historical records, power struggles and power conflicts are not only as depicted in the three novels, namely NA, NAD, and NMJ. This can be observed as in the era of Lord Singha. In the historical context of the power struggle, it is said that South Kalingga was attacked by Sanjaya. As a result of Sanjaya's attack, Lord Singha's throne was overthrown and then after the collapse of the South Kalingga power,
Sanjaya founded the Medang kingdom and Sanjaya crowned himself as king.

\section{A. NA Historical Links}

As long as the Medang kingdom was in power, its continuation was marked by acts of war and treason. The struggle for the throne of power was marked by acts of war. Among other things, the power struggle carried out by Rakai Panunggalan Dyah Dharanindra against the kings of Java, Sumatra and outside the archipelago, for example the kingdom of Campa and the kingdom of Cambodia. Then the incident of treason during the Medang kingdom in East Java was carried out during the reign of Dhamawangsa Teguh. This is the setting for the story in NA.

At the time Haji Wurawari, as the vassal king of Medang, rebelled against Dharmawangsa Teguh's power because he was not approved of marrying his daughter Dewi Laksmi. Makar Haji Wurawari against Dharmawangsa Teguh's power was successful because of the support of the Sriwijaya kingdom. The incident killed Dharmawangsa Teguh and the guests invited to the wedding reception of Dewi Laksmi and Airlangga. This event is known as mahapralaya (mass death).

As a result of the collapse of the Medang kingdom, Airlangga founded the Kahuripan kingdom. As the founder of the Kahuripan Kingdom, which ruled from 1009-1042, Airlangga was confirmed with the title Abhiseka Sri Maharaja Rakai Halu Sri Dharmawangsa Airlangga Anantawikramottunggadewa. Furthermore, at the beginning, Arilangga became king, he defeated King Hasin, Wisnuprabhawa (king of Wuratan), and Panuda (king of Lewa) in 1030. In 1032, Airlangga was attacked by troops from the daughter of the king of Panuda who ruled in the Tulungagung area. As a result, the Kahuripan kingdom was defeated. Together with Mapanji Tumanggala, Airlangga fled to Patakan Village. In 1032 also, Airlangga turned to attack and was able to conquer the daughter of the king of Panuda and at almost the same time the king of Airlangga succeeded in defeating Haji Wurawari and in 1035 he overcame the plot of king Wijayawarma from the Wengker kingdom.

During his reign, Airlangga as a king ordered Mpu Kanwa to change Arjunawiwaha's kakawin as a literary text describing his success in warfare. At the end of his reign, Airlangga had a policy over his kingdom. The Kahuripan kingdom was split in two into the Kadiri kingdom and the Janggala kingdom. King Airlangga's policy of dividing the kingdom was based on the problems of his two sons. Furthermore, In 1042, Airlangga stepped down after dividing the Kahuripan region into Janggala and Kadiri. Because Janggala was a strategic trading area, Kadiri tried master it.

\section{B. NAD Historical Links}

The historical link of NAD can be compared with historical information, when the Mapanji Jayabhaya government, the Janggala kingdom was successfully controlled. This background made Tumapel, which was originally a Janggala 
area, under the rule of Kadiri during the reign of King Kertajaya (1182-1222). At that time, the Tumapel area was led by an Akuwu named Tunggulametung. According to the Pararaton fiber, Akuwu Tunggulametung was killed by Ken Arok.

The motivation for the murder of Akuwu Tunggulametung by Ken Arok was because he wanted to marry Ken Dedes, who was believed to be a revelation keprabon (revelation of the king). As a link to the story, ken Arok had the support of Buddhist and Hindu priests who defected to Kertajaya. Ken Arok attacked Kadiri in 1222 so that the king of Kertajaya was conquered. Thanks to his victory over Kadiri, Ken Arok crowned himself as king in Tumapel, which was then known as the Singhasari kingdom since under the reign of King Ranggawuni or Wisnuwardhana.

The story of NAD became a critical transformation of the Pararaton fiber which became a historical reference providing a picture for five years (1222-1227), while in power Ken Arok was killed by Anusapati's son Ken Dedes and Akuwu Tunggulametung. By Mapanji Tohjaya (son of Ken Arok and Ken Umang), Anusapati was killed by him. By Ranggawuni (Anusapati's son), Tohjaya was successfully killed. Since then, Ranggawuni has crowned himself as king of Singhasari. After the reign of Ranggawuni (1254), Singhasari was controlled by Kertanagara (1254-1292).

During his time as king, Kertanagara expanded his territory through the Pamalayu Expedition. Because many of his troops were sent outside Java to realize this mission, Arya Wiraraja, who was disappointed because he was demoted by Kertanagara, instigated Jayakatwang (Duke of Gelanggelang) to rebel against Kertanagara's rule. The Jayakatwang rebellion reaped brilliant results.

\section{NMJ Historical Links}

The NMJ stated about power:

"Kekuasaan sejatinya tanpa batas, meski kekuasaan itu hanya sepengginang" [5].

"The true power is unlimited, even though that power is only equal" [5].

Jinggo is the name for Wirabumi. Jinggo is a term of inner banter Hayam Wuruk family (king of Majapahit). Minak Jinggo means an orange-faced aristocrat. Minak Jinggo became a mockery of the empress's family. This has made Breh Wirabumi excluded. Breh Wirabumi is close to commoners and farmers. He was actually the family of Hayam Wuruk from low-level circles who became the laughingstock of the royal family. Breh Wirabumi was hard-hearted. Majapahit was a large kingdom, and Hayam Wuruk would place Wirabumi as a kumararaja, resulting in disappointment because Sri Gitarja found it difficult to accept Wirabumi to inherit the throne. In NMJ the conflict developed into an interesting story over the power struggle in the Majapahit kingdom.
Henceforth the historical explanation related to the power struggle in the NMJ, it is explained from various references, that after Kertanagara died, Jayakatwang became king. Panji [6], but the center of government was not in Singhasari (Malang), but in Daha (Kadiri) in 1293. Not long-ago becoming king, Jayakatwang's power in Daha was overthrown by Dyah Wijaya (Kertanagara's son-in-law). The success of Dyah Wijaya's plot was due to the use of Tartar (Mongolian) troops and received support from his followers - Arya Wiraraja, Ranggalawe, Mpu Nambi, Lembu Sora, Mahisa Nabrang, and others. After the Tartar troops were driven out of Java, Dyah Wijaya founded the Majapahit Kingdom or Wilwatikta (Majakerta) in 1293. At the start of Dyah Wijaya's reign, Majapahit was faced with political intrigues by Halayuda (Kakawin Nagarakretagama) or Mahapati (Serat Pararaton). Thanks to his ambition to become a Rakryan Mapatih Majapahit, Halayuda got rid of key figures, including: Ranggalawe, Lembu Sora, and Mpu Nambi.

After the three key figures claimed by Dyah Wijaya to commit treason against his power were killed, Halayuda became the Rakryan Mapatih Majapahit during the Jayanagara administration (1309-1328). However, before the end of Jayanagara's reign, Halayuda, known as Sengkuni Majapahit, was killed by Bekel Jaka Mada (leader of the Bhayangkari army), who later became known as Gajah Mada. During the Jayanagara government era, Majapahit was colored by internal political intrigues that led to treason practices from its staff. It is proven at that time that several treason practices were carried out by Mandana, Pawagal and Ra Semi (1316); Mpu Nambi (1316); and Ra Kuti (1319). Makar Ra Kuti received support from Ra Yuyu, Ra Tanca, and Winehsuka's troops. As a result of Ra Kuti's plot, Jayanagara, who was escorted by Jaka Mada and his Bhayangkari troops, fled to Bedander Village. By Jaka Mada, Ra Kuti's treason was successfully crushed. After Majapahit's security was guaranteed, Jayanagara returned to the Majapahit palace.

Because he wanted the Majapahit throne not to fall outside of his descendants, Jayanagara wanted to edit Dyah Gitarja and Dyah Wiyat who were siblings of another mother's father. Jayanagara's desire was opposed by Jaka Mada. So, an interpretation emerged from some historians, Jaka Mada who ordered $\mathrm{Ra}$ Tanca (the royal physician) to kill Jayanagara. After Jayanagara died, Jaka Mada killed Ra Tanca. This was intended so that the mastermind who killed Jayanagara would not be loved by the royal family, the courtiers, and the people of Majapahit. After Jayanagara's death, Gayatri appointed Dyah Gitarja (Tribhuwana Wijayatunggadewi) to be king of Majapahit (1328-1350). During his reign, treason practices emerged from the Sadeng and Keta regions. By Adityawarman and Tribhuwana themselves, this plot was successfully eradicated.

In 1350, Tribhuwana Wijayatunggadewi resigned from the position of king to join as a member of Sapthaprabhu. As a replacement for the king of Majapahit was Hayam Wuruk. During the reign of Hayam Wuruk (1350-1389), there was a bloody incident due to the Bubat War. The war between 
Majapahit troops under the command of Rakryan Mahapatih Amangkubhumi Gajah Mada versus a group of brides from Sunda under the leadership of Maharaja Linggabuana. The war arose because Linggabuana was not willing to obey Gajah Mada's orders that Dyah Pitaloka Citraresmi be handed over to Hayam Wuruk as a sign of Sundanese submission to Majapahit, and not as a wife. After Hayam Wuruk's reign, Majapahit experienced a period of ebb and flow. During the reign of Wikramawardhana (1390-1428), there was the Paregrek War. Civil war between Wikramawardhana (West Majapahit) and Bhre Wirabhumi (East Majapahit) in 1404. This war resulted in the death of Bhre Wirabhumi at the hands of Bhra Narapati (Kakawin Nagarakretagama) or Raden Gajah (Serat Pararaton) in 1406. Apart from the Bubad War, the Paregreg War, and treason; Majapahit during the reign of Dyah Kertawijaya (1447-1451) was marked by the murder of the inhabitants of Tidung Gelating by Bhre Paguhan (son of Bhre Tumapel). A dark incident also happened to Dyah Kertawijaya.

According to Serat Pararaton, Dyah Kertawijaya stepped down after the coup and was killed by Rasajawardhana who later became king of Majapahit in 1451-1453. After the death of Rajasawardhana, Majapahit was in a government vacuum (1453-1456). During the reign of Dyah Suprabhawa (14661474), Majapahit was again hit by political turmoil. Dyah Suprabhawa was forced to leave the throne of power to flee to Dayo or Daha after being powerless to face the coup by Bhre Kertabhumi. After Dyah Suprabhawa left the palace, Bhre Kertabhumi ascended the throne as King of Majapahit with the capital at Majakerta (1474-1478).

\section{Discussion}

In general, novels are seen as one of the fictional genres that represent fragments of life over a longer period of time than the fragments that are told in short stories or shorter than romance stories. A novel is a fictional story that presents characters and a series of events along with a setting arranged through a thematic storyline. The characteristic of the novel is that there is a building of conflict and suspension in the story which causes changes in character behaviour. Based on the results of the descriptions of NA, NAD, and NMJ, Indonesian novels present the king as the main character of the novel. One of the uniqueness of the social, political, power, cultural and historical aspects of the king's figures in the novel text reflects and represents the situation of his time. If it is sequenced from the story depicted from the three novels referring to the period of the Kahuripan kingdom, the Singhasari kingdom and the Majapahit kingdom with the context of Minak Jinggo's rebellion as the king of Blambangan, in essence a novel can be seen as a portrait of a situation of power and as a socio-political reaction of an era.

On the other hand, NA, NAD, and NMJ are seen as literary works rather than historical works. As literary works, NA, $\mathrm{NAD}$, and NMJ are defined as works of art that can provide enjoyment because of the beauty built in them. Only literary works are the object of appreciation and literary study. Because of their potential, NA, NAD, and NMJ act as media to convey heroic values and for the image of the struggle for power involving the socio-political issues of the kingdoms of NA, $\mathrm{NAD}$, and NMJ influencing the ideological content in historical social relations to become a critical and dynamic treat in the context. learning and education from generation to generation according to socio-cultural conditions. As the reference of Indonesian literature studies NA, NAD, and NMJ as well as the existence of Indonesian literary works prove that NA, NAD, and NMJ as literary works not only have aesthetic peculiarities but also have unique ideas and attractiveness of socio-political problems over the power of the Javanese king who lifted up.

As an example, the initial image in NA is supported by historical information which reports that King Airlangga was born in 990. His father was Udayana, the king of the Bedahul Kingdom from the Warmadewa Dynasty. His mother was named Mahendradatta from the Isyana dynasty of the Medang kingdom. Airlangga married daughter Dharmawangsa Teguh in Watan, the capital of the Medang Kingdom (Maospati, Magetan Jatim). When the party was going on, the city of Watan was attacked by King Wurawari who was an ally of the Sriwijaya Kingdom. This incident is recorded in the Pucangan inscription, this attack occurred around the year 928 Saka. In the attack, Dharmawangsa Teguh was killed, while Airlangga escaped to the Wanagiri mountain forest accompanied by his assistant Mpu Narotama. At that time, he was 16 years old, since that incident he began living life as a hermit. Evidence of his legacy can be found in Sendang Made, Kudu, Jombang, East Java. After three years of living in the forest, Airlangga was visited by a people's envoy who asked him to rebuild the Medang kingdom, because the city of Watan had been destroyed, he built the town of Watan Mas near Mount Penanggungan. When he first ascended to the throne, his kingdom only covered Sidoarjo and Pasuruan, because after the death of Dharmawangsa Teguh, many subordinate areas had left. In 1023, the Srivijaya Kingdom, which became a great enemy of the Isyana House, was defeated by Rajendra Coladewa, the king of Colamandala from India. This made Airlangga free to prepare himself to conquer the island of Java.

Since 1025, Airlangga expanded his power and influence in line with the weakening of Sriwijaya. Initially what Airlangga did was to formulate strengths to re-establish the power of Wangsa Isnaya over the island of Java. However, at first it didn't go well, because according to the Terep inscription (1032), Watan Mas was then captured by the enemy, so Airlangga fled to Patakan Village. Based on the Kamalagyan inscription (1037), the capital of the kingdom had moved to Kahuripan (Sidoarjo). Airlangga first defeated King Hasin, 1030 defeated Wisnuprbhawa raja Wuratan, Wijayawarma raja Wengker, then Panuda raja Lewa. In 1032, Airlangga was defeated by a female king from Tulungagung, Watan Mas palace was destroyed. Airlangga was forced to flee to the village of Patakan accompanied by Mapanji Tumanggala, and built a new city in Kahuripan, in that same year King Wurawari was defeated along with Mpu Narotama. Finally, in 1035, Airlangga put down the rebellion of Wijayawarma king 
Wengker, which he had conquered before. Wijayawarma fled from the city of Tapa but was later killed by his own people. Compare [6-11].

In NAD it is not much different from Pramodya Ananta Toer's other works, it does not have a broad influence on Indonesian writers, and Sarjono's explanation that Pram's writing is written conventionally. His explanation in Rahman [12] thematically has a major influence not only in Indonesia but across Indonesian borders.

Comparing NA, NAD, and NMJ by examining the power of Javanese kings in the text of the novel by pointing to the formation of ecosystems and the value system of Javanese life, it is as if to juxtapose the writings of Suroso and Puji [13] on the compilation of literature, writers and the state as historical nostalgia and heroism, Javanese human history full of intrigue, division, resistance, heroism, struggle for rights, throne, property, dignity, and self-respect,

The study of Indonesian literary texts according to their history can be used to determine cultural awareness and historical awareness as represented by the author. The implication is that the historical study of literary texts is useful for observing the development of Indonesian culture. The same thing, the study of Indonesian literary texts is useful for seeing the representation of values and norms that are at the core of Indonesian culture, namely culture that is supported by the culture that lives and develops in the archipelago that dynamically comes into contact with other cultures through the process of acculturation, assimilation and dynamism. Likewise, from the point of view of the usefulness and quality of the texts of NA, NAD, and NMJ, at least it fulfils what Sumardjo and Saini [14] say about quality literature, including NA, NAD, and NMJ which are communicative and integrative literature. The study of the representation and reflection of the Javanese king in the novel text shows that the novels are representative of communicating historical facts with the literary world by integrating historical and literary explanations. As a function and an explanation of the sociology of literature of NA, NAD, and NMJ, in the combination of literature and history the text is a manifestation of creativity representation [15] based on the mimetic principles of NA, NAD, and NMJ not a pure imitation but as a picture of a more personal In general, the author subjectively communicates his knowledge as the existence of the text as a novel text not a history book. As a final explanation, NA, NAD, and NMJ refer to Ratna's [16] statement that reality is both a social and historical fact, literature and culture play an important role. In terms of the beauty of the NA, NAD, and NMJ texts, as said by Refly [17], two things depend on the object, namely the NA, NAD, and NMJ texts or the readers' perceptions that make literary texts with historical content as nostalgia that give readers pleasure.

\section{CONCLUSIONS}

NA, NAD, and NMJ are Indonesian novels that have links to the history of kingdoms in Java by presenting power conflicts during the days of the Kahuripan kingdom, the Singhasari kingdom and the Majapahit kingdom.

The conflict over the power of the Javanese king became interesting in the literary discourse raised by S.W. Warsito and Harmadi (NA), Pramodya Ananta Toer (NAD), and Langit Krisna Hariadi (NMJ) for their creativity and critical vision with a distinctively attractive and dynamic authorship style when interpreted hermeneutically and obtaining critical discourse analysis studies.

The NA, NAD, and NMJ studies have an educational function, namely, to sharpen skills in critical analysis of Indonesian literature, especially for the study of novel texts that represent power struggles in socio-political and linguistic contexts. As a suggestion, it can be used as material for educational studies, especially in assessing the extrinsicality of fictional prose texts in schools which can improve students' critical thinking or high order thinking skills.

\section{REFERENCES}

[1] D. Schriffin, Discourse Analysis (terjemahan A.S Ibrahim). Yogyakarta: Pustaka Pelajar, 2007

[2] N. Fairlough, Critical Discourse Analysis. New York: Roudledge, 2013.

[3] H. Warsito, Airlangga. Yogyakarta: Flash Books, 2010.

[4] P. A. Toer, Arok Dedes. Jakarta: Lentera Dipantara, 2009.

[5] L.K. Hariadi, Minak Jinggo Sekar Kedaton. Solo: Tiga Serangkai, 2013.

[6] T. Panji, Kitab Sejarah Terlengkap, Majapahit. Yogyakarta: Laksana, 2015.

[7] K. B. Adji, Istri-istri Raja Jawa. Yogyakarta: Araska, 2013.

[8] K. B. Adji, Babad Bumi Jawa. Yogyakarta: Araska, 2014.

[9] K. B. Adji, Balik Pesona dan Sisi Kelam Singhasari. Yogyakarta: Araska, 2016

[10] Suwardono, Tafsir Baru Kesejarahan Ken Arok. Yogyakarta: Penerbit Ombak, 2013

[11] Yongki, Legenda Ken Arok Ranggah Radjasa. Jakarta: Grasindo, 2004.

[12] J.D. Rahman, Tokoh sastra Indonesia Paling Berpengaruh. Jakarta: Gramedia, 2014.

[13] Suroso and Puji Santoso, Estetika, Sastra, Sastrawan, dan Negara. Yogyakarta: Pararaton, 2009.

[14] K. Sumardjo, Apresiasi Kesusastraan. Jakarta: Gramedia Pustaka utama, 1991.

[15] N.K. Ratna, Paradigma Sosiologi Sastra. Yogyakarta: Pustaka Pelajar, 2003

[16] N. K. Ratna, Sastra dan Cultural Studies. Yogyakarta: Pustaka Pelajar, 2005

[17] Refly, Bahasa Estetika Posmodern. Jakarta: Colibri, 2006. 